\title{
Comparison of the NMR and the Acid Value Determination Methods for Quality Control of Input Polysorbates
}

\author{
Ema Valentina Brovč, ${ }^{1,2}$ Stane Pajk, ${ }^{1}$ Roman Šink ${ }^{2}$ and Janez Mravljak ${ }^{1, *}$ \\ ${ }^{1}$ The Chair of Pharmaceutical Chemistry, University of Ljubljana, Faculty of Pharmacy, Aškerčeva 7, \\ SI-1000 Ljubljana, Slovenia \\ ${ }^{2}$ Drug Product Development Biosimilars, Formulation Development, Lek d.d., Kolodvorska 27, SI-1234 Mengeš, Slovenia \\ *Corresponding author: E-mail: janez.mravljak@ffa.uni-lj.si \\ phone.: +38614769500; fax: +38614258031
}

Received: 03-19-2019

\begin{abstract}
Polysorbates (PS) are the most common non-ionic surfactants used in protein formulations. Their degradation has been studied intensively in recent years. Ester bond hydrolysis is one of many pathways of PS degradation that can lead to accumulation of free fatty acids (FFAs) and particle formation. The distribution and quantity of FFAs in PSs impacts directly on product quality. Characterization of input PS is highly relevant, because the initial content of FFAs differs greatly between manufacturers. The purpose of this study was to set up a quick and simple analytical method for the quantitative evaluation of FFAs in PS. The content of FFAs was measured for selected PS 20 and 80, using two methods, ${ }^{1} \mathrm{H}$ nuclear magnetic resonance spectroscopy $\left({ }^{1} \mathrm{H} \mathrm{NMR}\right)$ and the European pharmacopoeia method for determining acid value $\left(\mathrm{I}_{\mathrm{A}}\right)$. These methods have been evaluated using the method of standard addition and, based on the results, they are interchangeable. It was concluded that ${ }^{1} \mathrm{H}$ NMR is a useful tool for quality control of input PS and a rapid method for indicating the rate of PS degradation by hydrolysis and oxidation. Further, a newly discovered impurity in PS raw material, the long chain ketone 12 -tricosanone, can be identified using ${ }^{1} \mathrm{H}$ NMR.
\end{abstract}

Keywords: Nuclear magnetic resonance; acid number; fatty acids; polysorbates; degradation.

\section{Introduction}

One of the aspects that are important during the development of a biopharmaceutical is its physical and chemical stability. The most common way to stabilize protein formulations is by the use of surfactants. ${ }^{1,2,3}$ PS are the most widely used non-ionic surfactants, but they are prone to degradation by hydrolysis and/or oxidation pathways. Degradation of PS not only reduces its concentration but can also lead to formation of various degradation products. Some of them are poorly soluble in water, including free fatty acids (FFAs), which could precipitate and form particles under long-term or accelerated storage conditions. Thus, one of the quality evaluation parameters that is an important indicator of PS degradation, is FFA content. ${ }^{4,5,6,7}$ Acid formation can be measured by varying the $\mathrm{pH}$ of the solution or by determining the total content of FFAs. Among the methods prescribed by the pharmacopoeia acid value $\left(\mathrm{I}_{\mathrm{A}}\right)$ is the only method that can detect higher FFAs content.

The characterization of PS is very important because they are in contact with the active pharmaceutical ingredient and other excipients. In the current study of Torosantucci et al., the binding of phenol to a model fusion protein as well as to PS 20 was investigated and successfully quantified via diffusion ordered ${ }^{1} \mathrm{H}$ nuclear magnetic resonance spectroscopy $\left({ }^{1} \mathrm{H}\right.$ NMR $) .{ }^{8}$ For the pharmaceutical industry, it is of key importance that the analytical methods used are comprehensive, rapid and simple. The main benefits of ${ }^{1} \mathrm{H}$ NMR spectroscopy are its high sensitivity with a minimal amount of the sample required compared to $I_{A}$. Sample preparation is very easy and rapid and does not require prior separation of PS constituents. Change in shift and/or the integration area of the proton signals can provide information about degradation mechanism, especially ester hydrolysis of PS. ${ }^{9,10,11,12}$ Verbrugghe et al. used dif- 
fusion ordered ${ }^{1} \mathrm{H}$ NMR to quantify non-esterified ethoxylates in PS surfactants. This is important since these do not contribute to stabilisation of therapeutic proteins. However, we focused on FFAs that contribute to the formation of particles. ${ }^{13}$

Determination of $\mathrm{I}_{\mathrm{A}}$ is a quantitative method used to determine the presence of acids in the sample under examined. According to the European pharmacopoeia (Ph. Eur.), $\mathrm{I}_{\mathrm{A}}$ is the number that expresses in milligrams the quantity of potassium hydroxide required to neutralise free acids present in $1 \mathrm{~g}$ of the substance. Ph. Eur. specifies a limit of $\mathrm{I}_{\mathrm{A}}$ for a PS 80 maximum of 2.0, while the Chinese Pharmacopoeia has the stricter requirements that the $\mathrm{I}_{\mathrm{A}}$ should be limited to not more than 1.0. In order to ensure high sensitivity of $\mathrm{I}_{\mathrm{A}}$ method both pharmacopoeias prescribe a large quantity of the tested PS sample $(10.00 \mathrm{~g})(\mathrm{Ph}$. Eur. 9.0, $0426(01 /$ 2018), Ph. Eur. 9.0, 0428 (01 / 2011)).

The main manufacturers offer PS samples of two different grades for pharmaceutical applications. Multicompendial grade PS 80 meets the specifications from some particular pharmacopoeias: United States, Ph. Eur., British and Japanese. The Chinese Pharmacopoeia recently established a set of stricter requirements for PS 80 intended for injections. A new generation of superior grade PSs has been introduced to the market. This grade is sometimes referred to as "super-refined" or "ultra-pure", depending on the vendor. "Super-refined" is usually claimed to contain low peroxide, low endotoxin, and low impurity levels, while "ultra-pure" in the case of PS 80 refers to an oleic acid (OA) component comprising $98 \%$ pure OA. Moreover, depending on manufacturer and supplier's lot, acid values vary greatly. ${ }^{9,14,15}$

\section{Experimental}

\section{1. Solvents and Reagents}

Lauric acid (LA) and OA were purchased from Sig-

Table 1. Analysed fresh PS samples.

\begin{tabular}{llc}
\hline Sample & Data & $\begin{array}{c}\text { Declared } \\
\text { acid value }\end{array}$ \\
\hline PS 20 & $\begin{array}{l}\text { Tween }^{\circledR} \text { 20 } \\
\text { Manufacturer: Sigma-Aldrich (USA) } \\
\text { Material number: P2287 }\end{array}$ & $\begin{array}{c}\text { no data } \\
\text { available }\end{array}$ \\
& Lot number: MKCD6838 & \\
\hline PS 80 & $\begin{array}{l}\text { Tween }{ }^{\circledR} \mathbf{8 0} \\
\text { Manufacturer: Sigma-Aldrich (USA) }\end{array}$ & $\begin{array}{c}\text { no data } \\
\text { available }\end{array}$ \\
& $\begin{array}{l}\text { Material number: P4780 } \\
\text { Lot number: BCBV4473 }\end{array}$ & \\
\hline (HX2) & $\begin{array}{l}\text { Tween }{ }^{\circledR} \text { 80 } \\
\text { Manufacturer: NOF Corporation (Japan) }\end{array}$ & $\mathbf{0 . 1}$ \\
& $\begin{array}{l}\text { Material number: no available data } \\
\text { Lot number: 612357Z2 }\end{array}$ \\
\hline
\end{tabular}

Table 2. Analysed PS samples with elapsed shelf life.

\begin{tabular}{|c|c|c|}
\hline Sample & Data & $\begin{array}{c}\text { Declared } \\
\text { acid value }\end{array}$ \\
\hline 1 & $\begin{array}{l}\text { Tween }{ }^{\circledR} \mathbf{2 0} \\
\text { Manufacturer: Sigma-Aldrich (USA) } \\
\text { Material number: P1378 } \\
\text { Lot number: SZBC2010V }\end{array}$ & 1.1 \\
\hline 2 & $\begin{array}{l}\text { Tween }{ }^{\circledR} \mathbf{2 0} \\
\text { Manufacturer: Merck KGaA (Germany) } \\
\text { Material number: } 817072 \\
\text { Lot number: K47210572 }\end{array}$ & 1.6 \\
\hline 3 & $\begin{array}{l}\text { Tween }{ }^{\circledR} \mathbf{2 0} \\
\text { Manufacturer: Merck KGaA (Germany) } \\
\text { Material number: } 817072 \\
\text { Lot number: K46977172 }\end{array}$ & 1.6 \\
\hline 4 & $\begin{array}{l}\text { Tween }{ }^{\circledR} \mathbf{2 0} \\
\text { Manufacturer: Merck KGaA (Germany) } \\
\text { Material number: } 817072 \\
\text { Lot number: K47210572 }\end{array}$ & 1.6 \\
\hline 5 & $\begin{array}{l}\text { Tween }{ }^{\circledR} \mathbf{2 0} \\
\text { Manufacturer: J.T.Baker (USA) } \\
\text { Material number: } 4116-04 \\
\text { Lot number: } 0000140208\end{array}$ & 1.3 \\
\hline 6 & $\begin{array}{l}\text { Tween }{ }^{\circledR} \mathbf{8 0} \\
\text { Manufacturer: Sigma-Aldrich (USA) } \\
\text { Material number: P4780 } \\
\text { Lot number: BCBG } 4950 \mathrm{~V}\end{array}$ & $\begin{array}{c}\text { no data } \\
\text { available }\end{array}$ \\
\hline 7 & $\begin{array}{l}\text { Tween }{ }^{\circledR} \mathbf{8 0} \\
\text { Manufacturer: Merck KGaA (Germany) } \\
\text { Material number: } 817061 \\
\text { Lot number: K46921061 }\end{array}$ & 1.4 \\
\hline
\end{tabular}

ma-Aldrich (USA) and Lauron (12-tricosanone) from Sigma-Aldrich (USA). Deuterated solvents: $\mathrm{CD}_{3} \mathrm{OD}, \mathrm{CDCl}_{3}+$ $0.03 \%$ TMS and DMSO- $d_{6}+0.03 \%$ TMS were purchased from Euriso-Top (France). All the information about the PS samples analysed is listed in Tables 1 and 2. Until the analysis all samples were stored at $2-8^{\circ} \mathrm{C}$ in the refrigerator.

\section{2. ${ }^{1} \mathrm{H}$ NMR}

Three parallel samples of fresh PS 20 and of PS 80 spiked (0-5\%) samples were weighed ( 150 mg), dissolved in $\mathrm{CD}_{3} \mathrm{OD}, \mathrm{CDCl}_{3}$ or DMSO- $d_{6}(450 \mu \mathrm{L})$, and transferred to $5 \mathrm{~mm}$ NMR tubes. Another parallel of expired samples was prepared in $\mathrm{CD}_{3} \mathrm{OD}$.

All ${ }^{1} \mathrm{H}-\mathrm{NMR}$ spectra were recorded using a Bruker AVANCE III $400 \mathrm{MHz}$ NMR spectrometer. Acquisition parameters were set according to Zhang et al.; spectral width was set to $20.55 \mathrm{ppm}$, acquisition time to $4.3 \mathrm{~s}$, relaxation delay to $20 \mathrm{~s}$ and number of scans to $16 .{ }^{12} \mathrm{In}$ order to cover $99 \%$ of the peak area, the integration region covers approximately 20 times the line width in 
each direction. In cases where signal overlap was too severe to allow appropriate integration regions, peak deconvolution was used.

\section{3. Lauric/Oleic Acid and Lauron Spiking}

In order to investigate the correlation between $\mathrm{I}_{\mathrm{A}}$ and NMR integrals of FFA using linear regression, samples of PS20 and PS80 were spiked with LA and OA, respectively. Two parallels of fresh PS 20 and PS 80 samples with different FFA contents were prepared $-1 \%, 2 \%, 3 \%, 4 \%$ and $5 \%$ $(\mathrm{w} / \mathrm{w})$ (Figures S1 and S2). The samples were sealed under argon atmosphere and tightly closed with parafilm, stirred on a magnetic stirrer for approximately 6 hours at $300 \mathrm{rpm}$ to give a homogeneous mixture. During mixing, the first parallel of the LA spiked samples was also heated in a sand bath, at $50^{\circ} \mathrm{C}$ because of the LA melting temperature, which is approximately $45^{\circ} \mathrm{C}$ in the solid state. Additionally, PS 20 samples were spiked with $5 \%(\mathrm{w} / \mathrm{w})$ lauron in order to evaluate the presence of lauron in the raw PSs material.

\section{4. Determination of $I_{A}$}

$\mathrm{I}_{\mathrm{A}}$ was determined according to the procedure for testing PS 20 and PS 80, and prescribed in the Ph. Eur. 9.0. Approximately $10.0 \mathrm{~g}$ of sample was weighed into a 100 $\mathrm{mL}$ flask. $50 \mathrm{~mL}$ of a $1: 1(\mathrm{v} / \mathrm{v})$ mixture of $96 \%$ ethanol and petroleum ether was added and mixed well. $0.5 \mathrm{~mL}$ of phenolphthalein solution R1 indicator was added to the sample solutions. The sample solutions were titrated with a $0.1 \mathrm{M} \mathrm{NaOH}$ solution until the pink colour persisted for at least $15 \mathrm{~s}$.

\section{Results and Discussion}

\section{1. ${ }^{1} \mathrm{H}$ NMR}

In order to establish the correlation between ${ }^{1} \mathrm{H}$ NMR and $\mathrm{I}_{\mathrm{A}}$, a spiking study was carried out. Lauric and oleic acids were chosen because they form the main FA moiety of PS 20 and PS 80, respectively. The established method was tested on a series of PS 20 and PS 80 elapsed shelf life samples. The resulting values of the measured $\mathrm{I}_{\mathrm{A}}$ were compared with those of $\mathrm{I}_{\mathrm{A}}$ listed in the specifications of the individual PS sample.

The individual functional groups of PS 80 that correspond to the signals in the ${ }^{1} \mathrm{H}$ NMR spectra are shown in Figure 1. The main PS 80 peaks had already been charac-

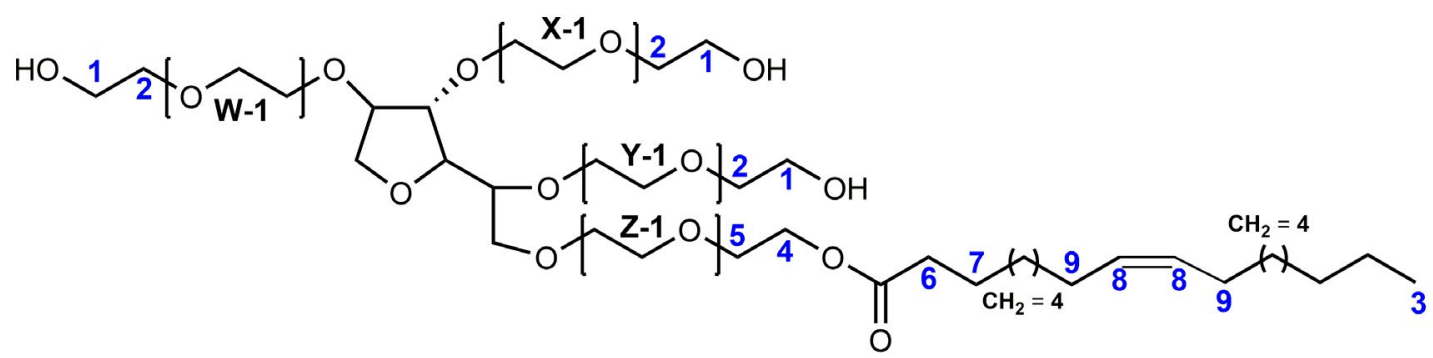

Fig 1. Chemical structure of PS $80, X+Y+Z+W=20$.

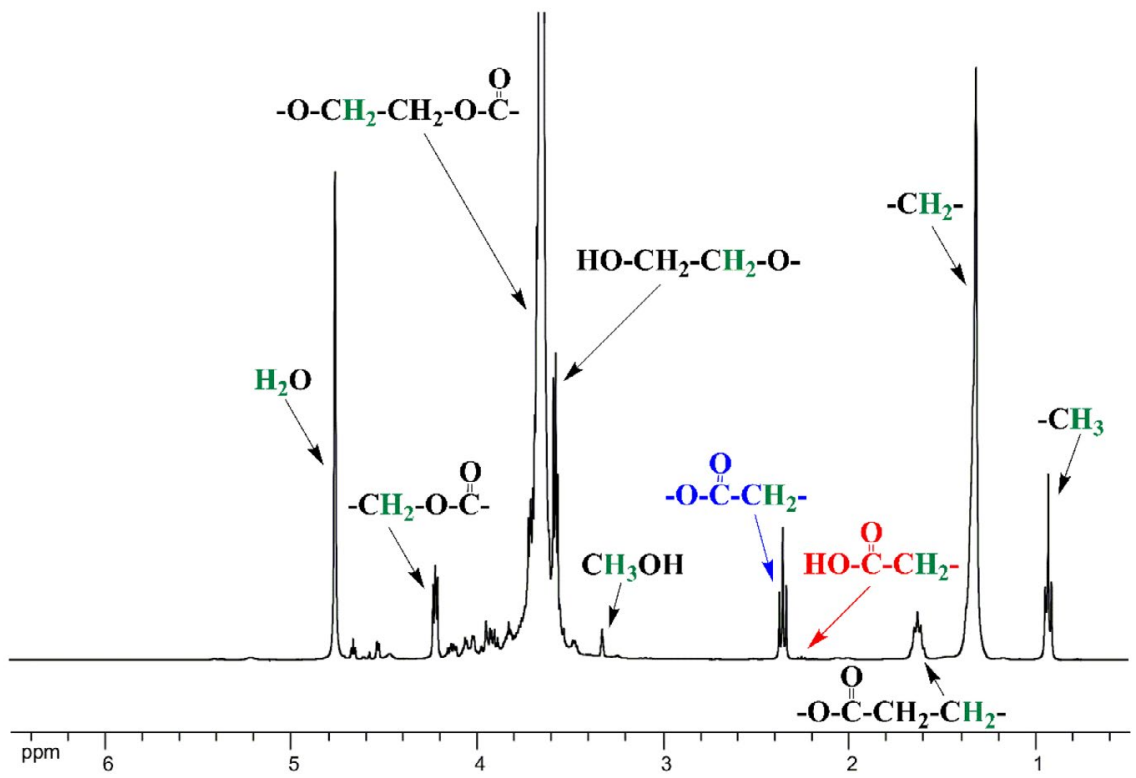

Fig 2. ${ }^{1} \mathrm{H}$ NMR spectrum of the fresh PS 20 sample recorded in $\mathrm{CD}_{3} \mathrm{OD}$. 


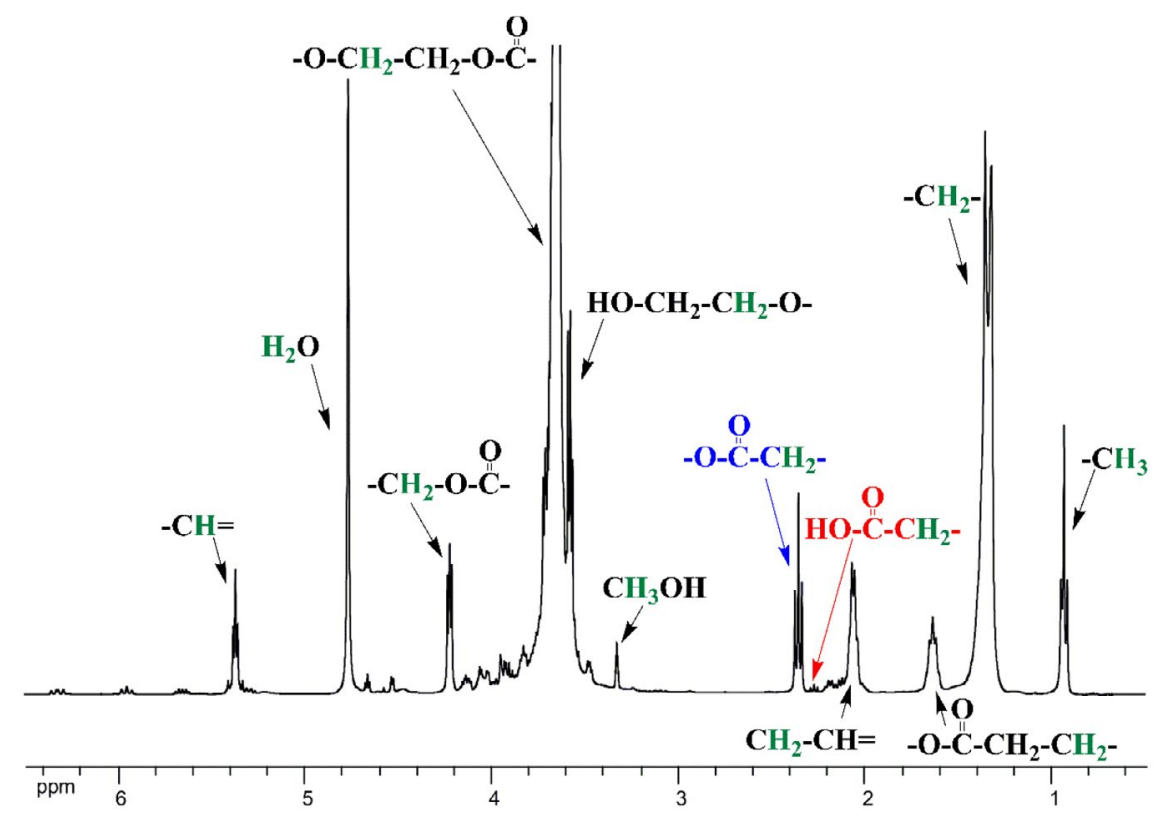

Fig 3. ${ }^{1} \mathrm{H}$ NMR spectrum of the fresh PS 80 sample recorded in $\mathrm{CD}_{3} \mathrm{OD}$.

terized. ${ }^{12}$ Only spectra recorded in $\mathrm{CD}_{3} \mathrm{OD}$ were used for comparison and evaluation of the obtained results; explanation of solvent selection is discussed below. The spectra were normalized by integrating the $\mathrm{CH}_{2}$ group at 2.36 ppm. The a-methylene groups of FFAs present in PS exhibit a distinctive chemical shift at $2.26 \mathrm{ppm}$ (marked with red in Figures 2 and 3) clearly separable from those of esterified FAs (marked with blue in Figures 2 and 3).

The molar ratio between FFAs and esterified FA was determined by comparing their respective ${ }^{1} \mathrm{H}$ NMR signals for a-methylene groups (Figure 4). The signals for FFAs (2.26 ppm) and esterified FAs (2.36 ppm) are clearly separated and, most importantly, could be integrated separately. The values of integrals for esterified FA were set to 1 , while those for FFA integrals are reported relative to the first ones. The ratios between integrals were then compared. On the other hand, signals in ${ }^{1} \mathrm{H}$ NMR spectrum corresponding to sorbitan polyoxyethylene (POE) of degraded and nondegraded PS 20 are practically indistinguishable as reported by Khossravi et al. and cannot be used to determine the ratio between nonesterified and esterified sorbitan POE. ${ }^{16}$ Quantification of nonesterified and esterified sorbitan POE is important, since nonesterified sorbitan POE may be present as impurity arising from PS synthesis without elevated levels of FFAs. ${ }^{13}$ Perhaps the ratio between integrals of esterified FAs and sorbitan POE could indicate the presence of nonesterified sorbitan POE, however this is beyond the scope of this article.

In the ${ }^{1} \mathrm{H}$ NMR spectra, the most signals for PS constituents are well separated when recorded in $\mathrm{CDCl}_{3}$, however the signals for FAs and FFAs are partly overlapping (Figures S5 and S6). Additionally, the chemical shift of the signal for the a-methylene group of FFAs depends on the percentage of added FA. However, for the samples of PS 20 recorded in DMSO- $d_{6}$, the signals are sufficiently apart, although there is overlapping of $\alpha$-methylene peaks with other signals in the spectra of PS 80 (Figures S3 and S4). Signals for esterified FAs and FFAs are sufficiently separated in samples recorded in $\mathrm{CD}_{3} \mathrm{OD}$ to allow accurate integration. Only spectra recorded in $\mathrm{CD}_{3} \mathrm{OD}$ were used for comparison and evaluation of obtained results.

The results of the ${ }^{1} \mathrm{H}$ NMR method are given below as the molar percentage $(\mathrm{n} / \mathrm{n})$ of FFA molecules relative to that of all FA molecules (esterified and free) in the samples. The molar percentages of FFA were calculated (Equation S1) from the corresponding integrals of the signals belonging to FFA $\alpha$-methylene and esterified FA (Figure 5).

\section{2. Determination of $I_{A}$}

Values of $\mathrm{I}_{\mathrm{A}}$ were calculated by considering the mass of weighed samples and the consumption of $\mathrm{NaOH}$ solution (Equation S2). Unlike the results obtained using the ${ }^{1} \mathrm{H}$ NMR method, the values of $\mathrm{I}_{\mathrm{A}}$ represent the content of all FAs in the sample, including formic acid, acetic acid and other organic acids (Figure 5).

\section{3. Method Correlation and Comparison of ${ }^{1} \mathrm{H}$ NMR and $\mathrm{I}_{\mathrm{A}}$ Results}

Using linear regression, the square of the correlation coefficient $\left(\mathrm{R}^{2}\right)$ was calculated for both PS 20 and PS 80 samples examined by the ${ }^{1} \mathrm{H}$ NMR and $\mathrm{I}_{\mathrm{A}}$ methods. It shows the percentage of the total variance of the variable $y$ 

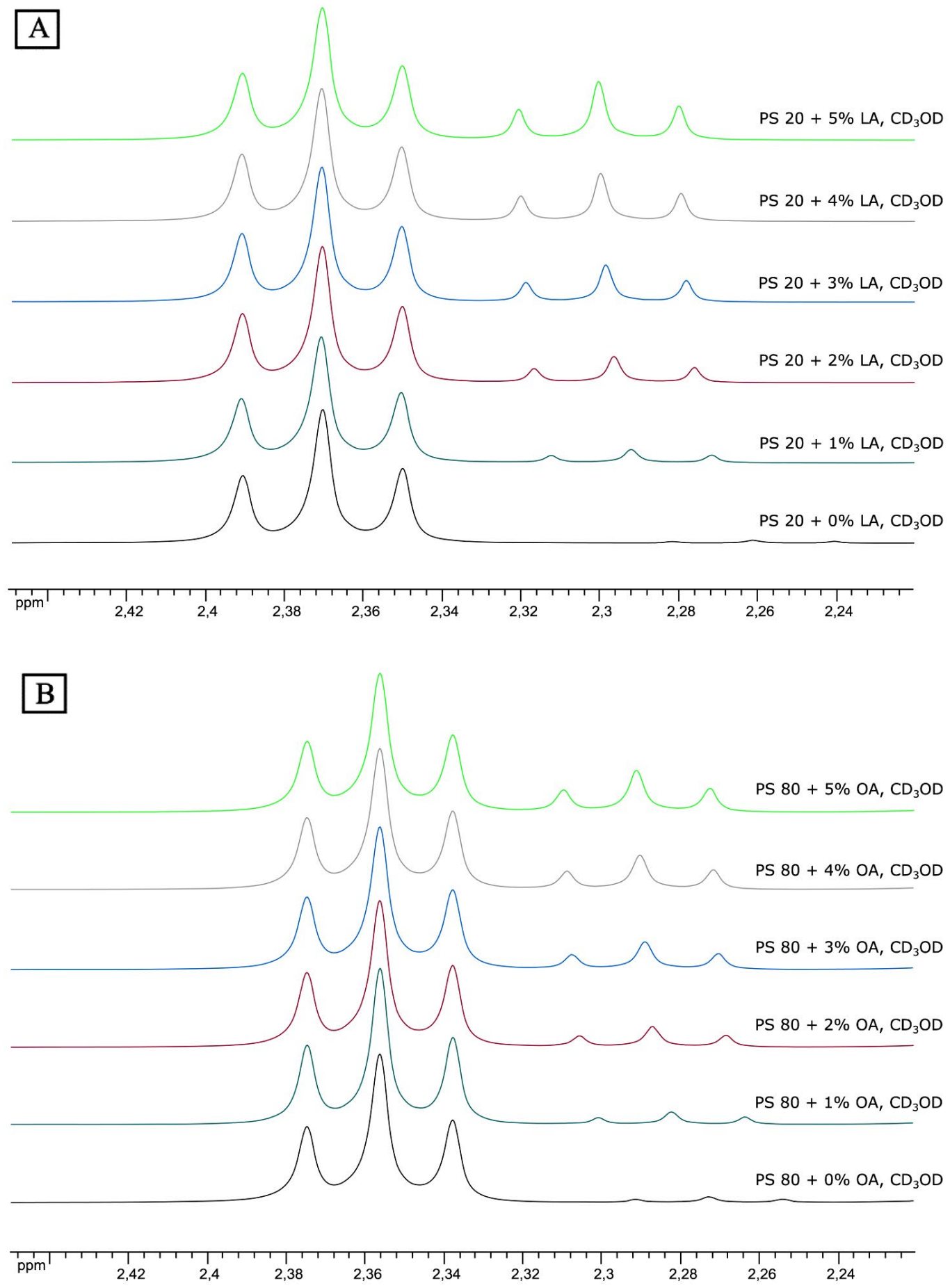

Fig 4. Comparison of spectra for PS 20 (A) and PS 80 (B) in $\mathrm{CD}_{3} \mathrm{OD}$ after spiking with LA or OA.

(\% FFAs and values of $\mathrm{I}_{\mathrm{A}}$ ) with respect to the variable $\mathrm{x}(\%$ spiked FA). For evaluation of the methods, correlation $\mathrm{R}^{2}$ values were rooted. The Pearson correlation coefficient $(\mathrm{R})$ values obtained are very close to 1 , which indicates that the calculated values of $\%$ FFAs and of the $\mathrm{I}_{\mathrm{A}}$ are highly dependent on \% spiked FA in PS samples, which is expected (Figure 6). The values obtained vary only slightly and depend strongly on each other. It can be concluded that there is a good correlation between the two methods and that the methods are comparable to each other.

From the results of ${ }^{1} \mathrm{H}$ NMR (Tables S1 and S2) and $\mathrm{I}_{\mathrm{A}}$ (Tables S3 and S4) determination it is seen that the values of FFA and $\mathrm{I}_{\mathrm{A}}$ in the PS 20 samples increase more rapidly with increasing the \% LA than those in the corresponding PS 80 samples with increasing the \% OA. The reason for the difference lies in the molecular weight of 

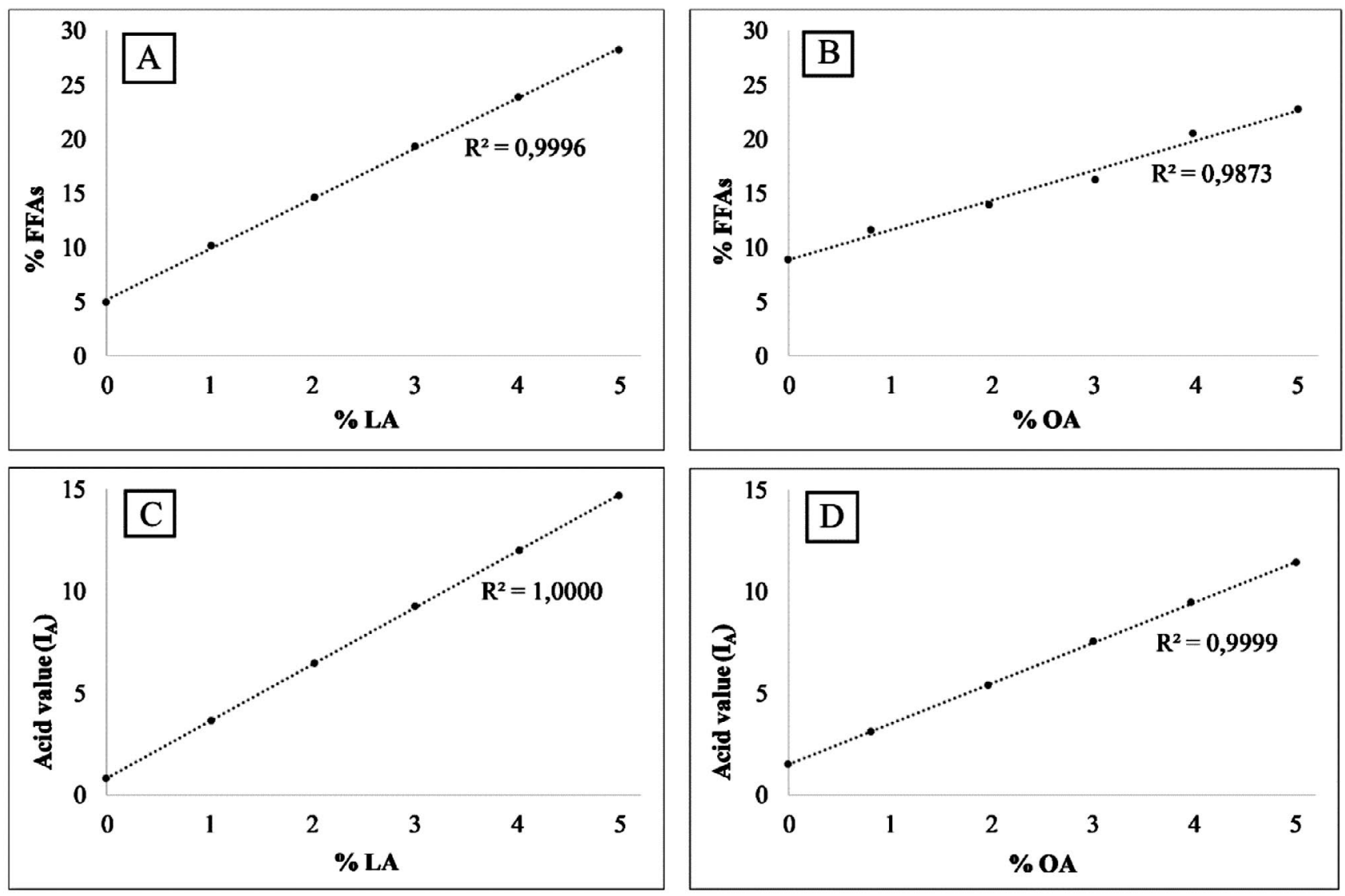

Fig 5. Values of \% FFAs (n/n \%) relative to \% LA (w/w) in PS $20(A)$, values of $\%$ FFAs $(n / n)$ relative to \% OA (w/w) in PS 80 (B), $I_{A}$ values relative to $\% \mathrm{LA}(\mathrm{w} / \mathrm{w})$ in PS $20(\mathrm{C})$ and $\mathrm{I}_{\mathrm{A}}$ values relative to $\% \mathrm{OA}(\mathrm{w} / \mathrm{w})$ in PS $80(\mathrm{D})$.
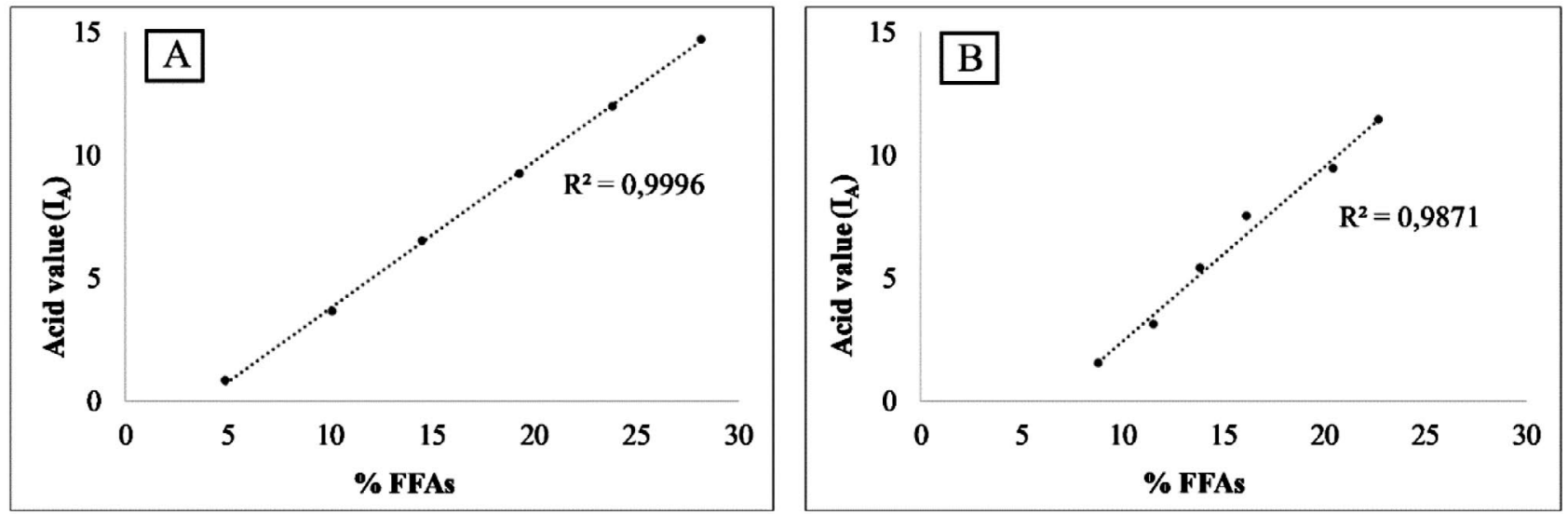

Fig 6. $\mathrm{I}_{\mathrm{A}}$ values in correlation to $\%$ FFAs (w/w) in PS 20 (A) and PS 80 (B) samples.

added FA; the same added mass of FA corresponds to more moles in the case of LA.

\section{4. Benefits of ${ }^{1} \mathrm{H}$ NMR Method}

${ }^{1} \mathrm{H}$ NMR enables comprehensive PS structural information in terms of quality control of input PS and differentiation between PS 20 and PS 80 of different quality grades.
Long-chain ketone lauron (12-tricosanone) is a newly identified impurity present already in specific PS raw material lots and is not a degradation product. It is poorly soluble in water and therefore forms visible particles in protein formulations. ${ }^{17}$ In spiked PS 20 samples, the lauron signal is well separated from the a-methylene group signal for esterified FA and FFAs. Using the ${ }^{1} \mathrm{H}$ NMR method, lauron can be easily identified (Figure 7). 


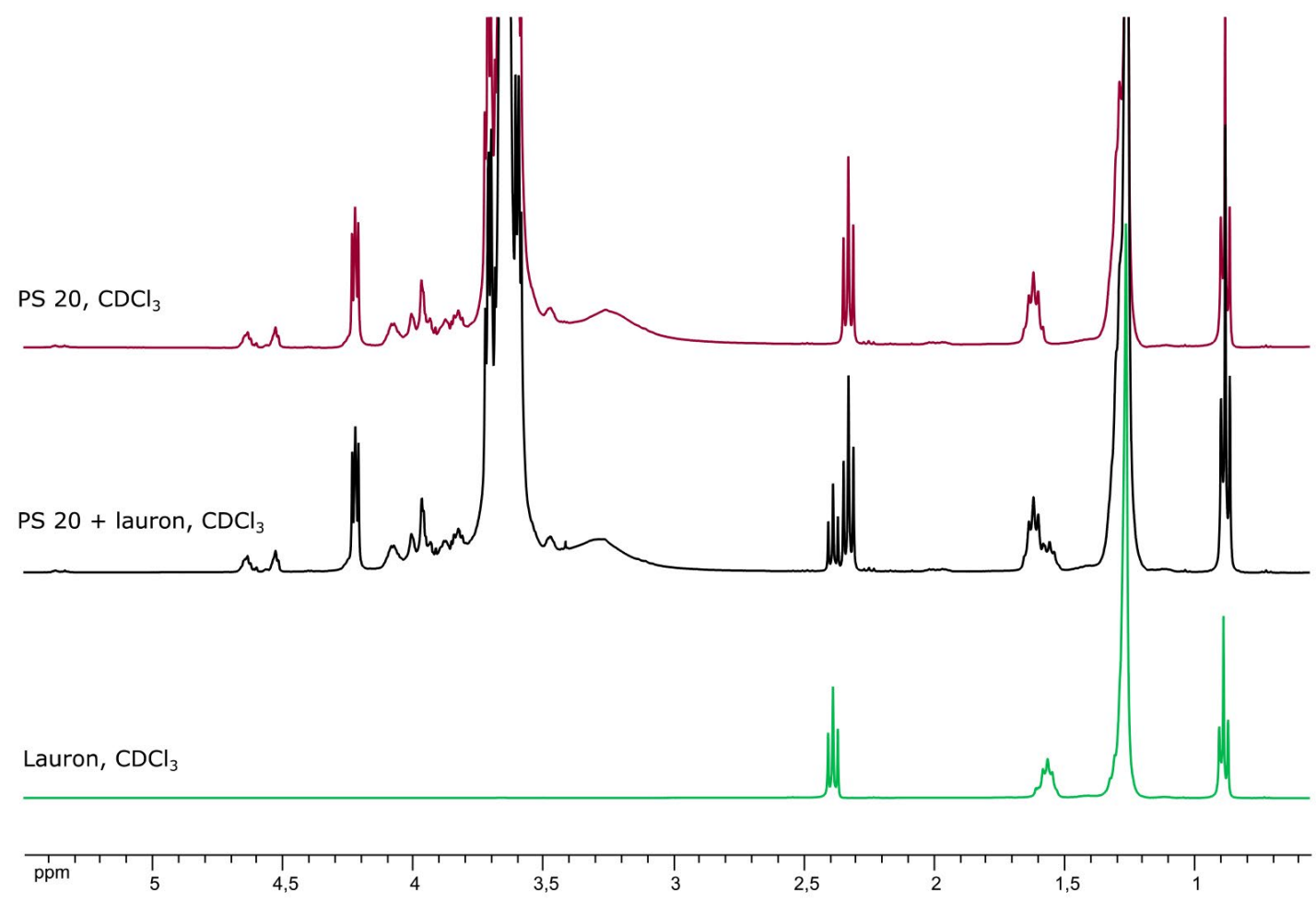

Fig 7. Comparison of raw PS $20{ }^{1} \mathrm{H}$ NMR spectra, lauron spiked (10\% w/w) PS $20{ }^{1} \mathrm{H}$ NMR spectra and lauron ${ }^{1} \mathrm{H}$ NMR spectra.

${ }^{1} \mathrm{H}$ NMR can also be used as a stability indicating method for PS degradation. One big difference between PS 20 and PS $80{ }^{1} \mathrm{H}$ NMR spectra is that signals belonging to the OA double bond, which is found only in PS 80, are seen as $-\mathrm{CH}=$ and $-\mathrm{CH}_{2}-\mathrm{CH}=$ groups. The first one is visi- ble at a chemical shift of about $5.4 \mathrm{ppm}$ and is a signal for the $\mathrm{CH}$ groups at the double bond in the FA chain, marked by the number 8 in Figure 1. The second is visible at a chemical shift of about $2.0 \mathrm{ppm}$ and constitutes a signal for the following double bond adjacent to the $\mathrm{CH}_{2}$ group in
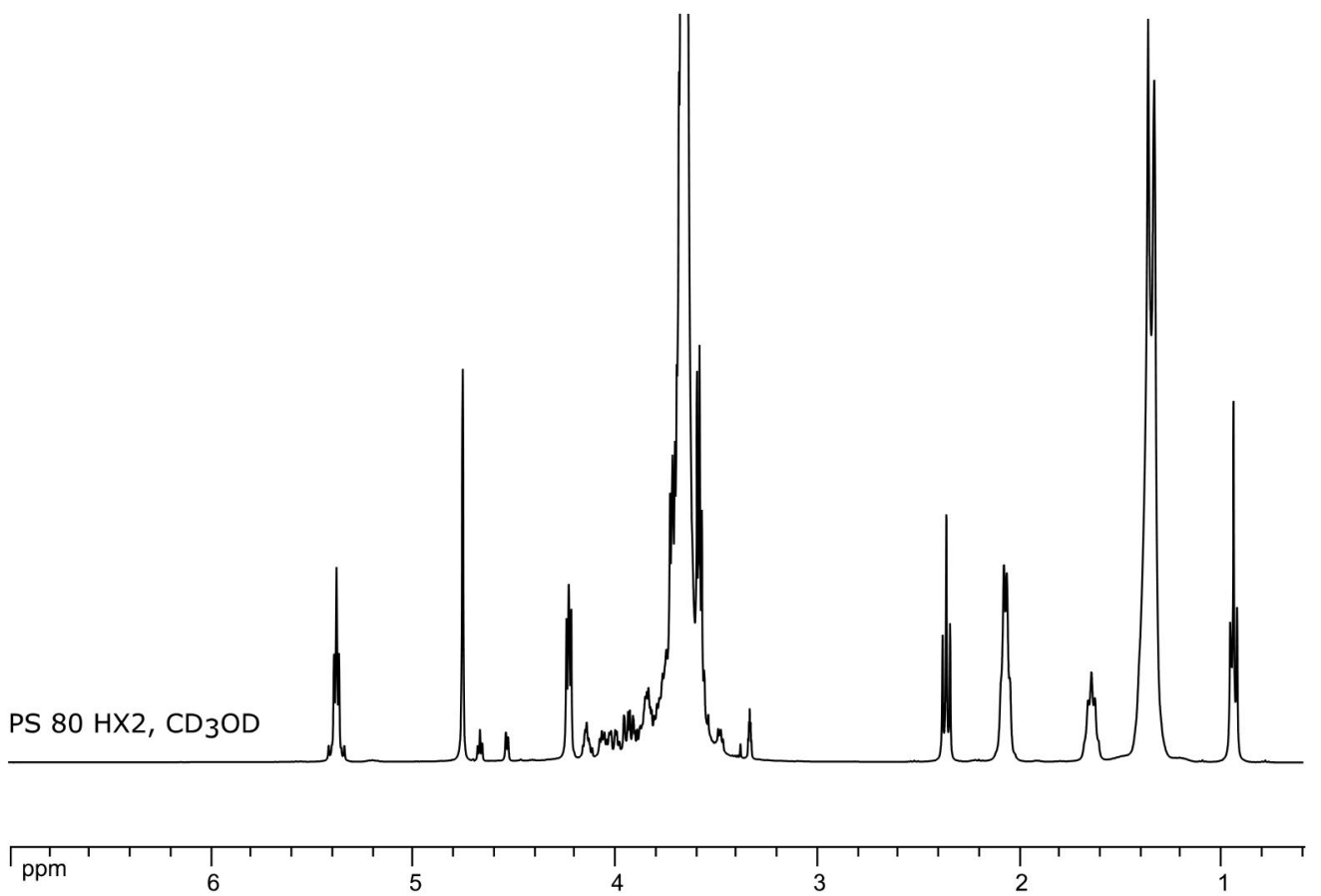

Fig 8. ${ }^{1} \mathrm{H}$ NMR spectrum, recorded in $\mathrm{CD}_{3} \mathrm{OD}$, of the fresh "ultra-pure" PS 80 sample. In comparison to the spectrum of "multicompendial-grade" PS 80 (Figure 3) the triplet at 2.3 ppm belonging to FFA is absent, indicating that there is no FFA in the sample. 
the FA chain, marked by a number 9 in Figure 1. The proportion of OA in the FA fraction can be estimated from the ratio of the double bond integral at $5.4 \mathrm{ppm}$ to that at 0.9 ppm of the terminal $\mathrm{CH}_{3}$ group protons.

During their study of the thermal oxidation of PS 80, using ${ }^{1} \mathrm{H}$ NMR, Hvattum et al. discovered that about $9 \%$ of all FAs present contained a $Z E$ or $E Z$ conjugated double bond. ${ }^{18}$ We can also confirm the presence of conjugated $(9 Z, 11 E)$-linoleic acid, which has multiple double bonds seen as an additional 4 signals ranging from 5 to $6 \mathrm{ppm}$. The described signals were seen only in multicompendial grade PS 80 in Figure 2, not in the "ultra-pure" one in Figure 8. Conjugated double bond FAs are more susceptible to auto-oxidation than FAs with isolated double bound, so their characterization already in raw PS samples is very important.

\section{5. Comparison of the Results of the Use of ${ }^{1} \mathrm{H}$ NMR and $\mathrm{I}_{\mathrm{A}}$ for Elapsed Shelf Life Samples}

The content of FFAs in the samples with elapsed shelf life was determined relative to the total content of FA. Seven randomly selected elapsed shelf life PS samples were analyzed in order to confirm the correlation of ${ }^{1} \mathrm{H}$ NMR and $I_{A}$ methods (Table 3). From the results for elapsed shelf life PS samples, maximum values of $\%$ FFA and $\mathrm{I}_{\mathrm{A}}$ were found in sample 6 , which is expected since it is the oldest sample according to the date of production (October 2011). The value determined exceeded the maximum allowable value of $\mathrm{I}_{\mathrm{A}}$ for PS $80,2.0$, as prescribed by $\mathrm{Ph}$. Eur. 9.0. The same trend was observed in sample 1 which, according to the date of production (July 2012), is the second oldest sample in the analysed PSs. In all other samples, the $\mathrm{I}_{\mathrm{A}}$ values were still within $\mathrm{Ph}$. Eur. specifications, despite their expiry date.

Comparing samples 1, 2 and 4 , the values of \% FFAs are seen to be practically the same (around 7\%), while
Table 3. The integral values of signals relating to FFA $\alpha$-methylene groups and their measured $\mathrm{I}_{\mathrm{A}}$ values.

\begin{tabular}{ccc}
\hline Sample & \% FFAs & $\mathbf{I}_{\mathbf{A}}$ \\
\hline $\mathbf{1}$ & 7.41 & 2.3 \\
$\mathbf{2}$ & 7.06 & 1.8 \\
$\mathbf{3}$ & 4.76 & 1.7 \\
$\mathbf{4}$ & 7.06 & 1.8 \\
$\mathbf{5}$ & 4.40 & 1.3 \\
$\mathbf{6}$ & 10.63 & 2.7 \\
$\mathbf{7}$ & 7.49 & 1.5 \\
\hline
\end{tabular}

those of $\mathrm{I}_{\mathrm{A}}$ vary greatly between sample 1 and samples 2 and 4 (Figure 9). The fact that $\mathrm{I}_{\mathrm{A}}$ values give an indication of all the acids present in the sample must be considered, while the ${ }^{1} \mathrm{H}$ NMR values exclude the content of formic, acetic and other organic acids. If there was autoxidation along the ethylene oxide portion of the PS during storage, short-chain fatty acids, such as formic and acetic acid, would result in increased $\mathrm{I}_{\mathrm{A}}$ values. An increase in $\mathrm{I}_{\mathrm{A}}$ in sample 1 can therefore be interpreted as a consequence of oxidation processes.

\section{Conclusions}

The content of FFAs is an important indicator of PS degradation, especially ester hydrolysis, and therefore a useful parameter from the standpoint of PS stability testing. The source of FFAs present in PS could be either degradation processes or synthesis. The distribution and quantity of FFAs in PSs impact on the product quality. Accumulated FFAs, which are insoluble in water, could ultimately precipitate to form visible particles. In this study, the ${ }^{1} \mathrm{H}$ NMR method and the pharmacopoeia method for determination of $\mathrm{I}_{\mathrm{A}}$ were compared. In the case of FFAs, the results obtained by the two methods

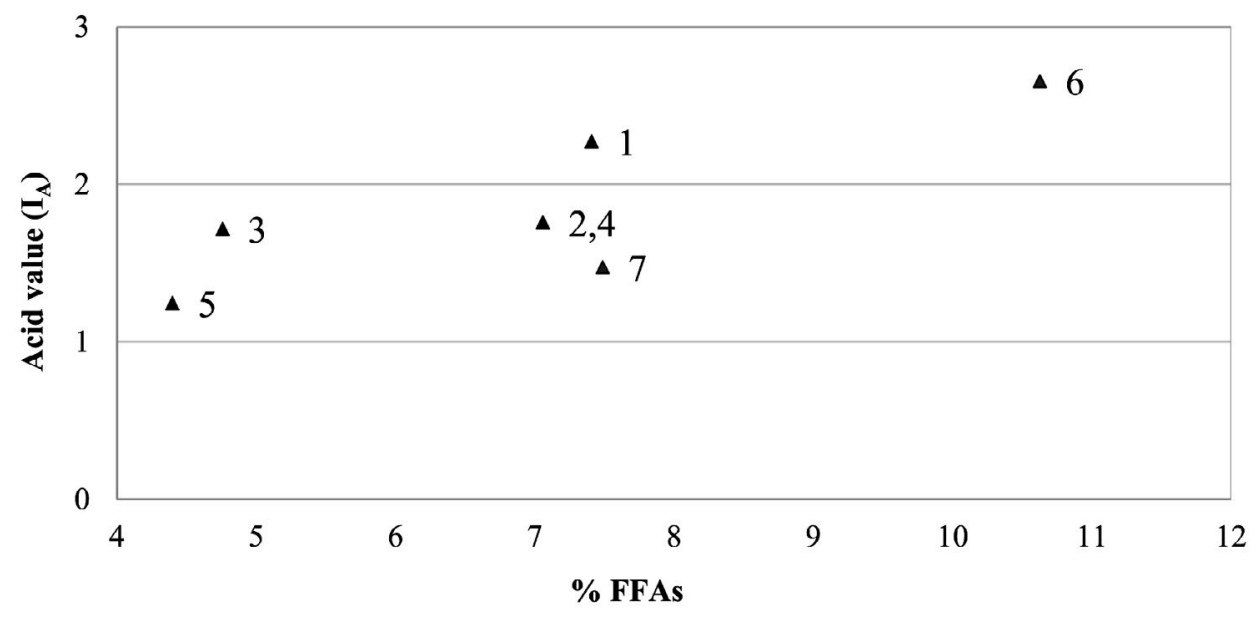

Fig 9. $I_{A}$ values correlated to the \% FFAs (w/w) in PS 20 (1-5) and PS 80 samples $(6,7)$. 
correlate strongly with each other. However, the pharmacopoeia $\mathrm{I}_{\mathrm{A}}$ method is non-specific and measures the total amount of acidic components whereas, with ${ }^{1} \mathrm{H}$ NMR, the amount of FFAs could be measured specifically. Additional benefits of ${ }^{1} \mathrm{H}$ NMR method are, especially, the much simpler and faster sample preparation and the lower amounts of sample needed when comparing with the $\mathrm{I}_{\mathrm{A}}$ determination method. The ${ }^{1} \mathrm{H}$ NMR method gives comprehensive PS structural information, information of PS degradation and the impurity profile. It could be definitively used as alternative method for monitoring PS degradation, instead of decrease in PS POE part, is much easier to monitor increase in FFAs signals as we have shown in our manuscript. Moreover, a newly discovered impurity in PS raw material, the long chain ketone lauron (12-tricosanone), can be identified using ${ }^{1} \mathrm{H}$ NMR.

\section{Abbreviations}

FA Fatty acid

FFAs Free fatty acids

IA Acid value

LA Lauric acid

NMR Nuclear magnetic resonance spectroscopy

OA Oleic acid

POE Polyoxyethylene

PS Polysorbate

$\mathbf{R}^{2} \quad$ Square of the correlation coefficient

RSD Relative standard deviation

\section{References}

1. H.-C. Mahler, F. Senner, K. Maeder, R. Mueller, J. Pharm. Sci. 2009, 98, 4525-33. DOI:10.1002/jps.21776

2. S. Kiese, A. Papppenberger, W. Friess, H.C. Mahler, J. Pharm. Sci. 2008, 97, 4347-66. DOI:10.1002/jps.21328

3. P. Garidel, C. Hoffmann, A. Blume, Biophys. Chem. 2009, 143, 70-8. DOI:10.1016/j.bpc.2009.04.004

4. R. S. K. Kishore, S. Kiese, S. Fischer, A. Pappenberger, U. Grauschopf, H.C. Mahler, Pharm. Res. 2011, 28, 1194-210. DOI:10.1007/s11095-011-0385-x

5. X. Cao, R.M. Fesinmeyer, C. J. Pierini, C. C. Siska, J. R. Litowski, S. Brych et al., J. Pharm. Sci. 2015, 104, 433-46.

DOI:10.1002/jps.24126

6. A. W. Ralston, C. W. Hoerr, J. Org. Chem. 1942, 7, 546-55. DOI:10.1021/jo01200a013

7. N. Doshi, B. Demeule, S. Yadav, Mol. Pharm. 2015, 12, 3792804. DOI:10.1021/acs.molpharmaceut.5b00310

8. R. Torosantucci, B. Furtmann, B. Elshorst, S. Pfeiffer-Marek, T. Hartleb, N. Andres et al., J. Pharm. Sci. 2018, 107, 2531-7. DOI:10.1016/j.xphs.2018.05.021

9. A. Martos, W. Koch, W. Jiskoot, K. Wuchner, G. Winter, W. Friess et al., J. Pharm. Sci. 2017, 106, 1722-35.

DOI:10.1016/j.xphs.2017.03.001
10. H. Vu Dang, A. I. Gray, D. Watson, C. D. Bates, P. Scholes, G. M. Eccleston, J. Pharm. Biomed. Anal. 2006, 40, 1155-65. DOI:10.1016/j.jpba.2005.10.007

11. Z. Wu, Q. Zhang, N. Li, Y. Pu, B. Wang, T. Zhang, J. Sep. Sci. 2017, 40, 288-98. DOI:10.1002/jssc.201600707

12. Q. Zhang, A. Wang, Y. Meng, T. Ning, H. Yang, L. Ding et al., Anal. Chem. 2015, 87, 9810-6.

DOI:10.1021/acs.analchem.5b02096

13. M. Verbrugghe, E. Cocquyt, P. Saveyn, P. Sabatino, D. Sinnaeve, J. C. Martins et al., J. Pharm. Biomed. Anal. 2010, 51, 583-9. DOI:10.1016/j.jpba.2009.09.025

14. S. R. Singh, J. Zhang, C. O’Dell, M.-C. Hsieh, J. Goldstein, J. Liu et al., AAPS PharmSciTech. 2012, 13, 422-30. DOI:10.1208/s12249-012-9759-6

15. A. C. McShan, P. Kei, J. A. Ji, D. C. Kim, Y. J. Wang, PDA J. Pharm. Sci. Technol. 2016, 70, 332-45. DOI:10.5731/pdajpst.2015.005942

16. M. Khossravi, Y.-H. Kao, R. J. Mrsny, T. D. Sweeney, Pharm. Res. 2002, 19, 634-9. DOI:10.1023/A:1015306112979

17. V. Hampl, X. Guo, C. Ehrenstrasser, M. Viertler, L. Rayner, G. Campanelli et al., J. Pharm. Sci. 2018, 107, 1552-61. DOI:10.1016/j.xphs.2018.02.017

18. E. Hvattum, W. L. Yip, D. Grace, K. Dyrstad, J. Pharm. Biomed. Anal. 2012, 62, 7-16. DOI:10.1016/j.jpba.2011.12.009 


\section{Povzetek}

Polisorbati (PS) so najpogosteje uporabljene neionske površinsko aktivne snovi $\mathrm{v}$ formulacijah s proteini. Njihovo razgradnjo so v zadnjih letih intenzivno proučevali. Hidroliza estrske vezi je ena od številnih razgradnih poti polisorbatov, ki lahko vodi v kopičenje prostih maščobnih kislin (FFAs) in v tvorbo delcev. Razporeditev in količina FFAs v PS neposredno vplivata na kakovost končnega izdelka. Karakterizacija vhodnega PS je izredno pomembna, saj se začetna vsebnost FFAs med različnimi proizvajalci zelo razlikuje. Namen naše študije je bil razviti hitro in enostavno metodo za kvantifikacijo FFAs v PS. Vsebnost FFAs smo izmerili izbranim vzorcem PS 20 in $80 \mathrm{z}$ uporabo dveh metod, z metodo protonske jedrske magnetne resonančne spektroskopije ( $\left.{ }^{1} \mathrm{H} \mathrm{NMR}\right)$ in $\mathrm{s}$ farmakopejsko metodo določanja kislinskega števila $\left(\mathrm{I}_{\mathrm{A}}\right)$. Metodi smo ovrednotili $\mathrm{z}$ uporabo metode standardnega dodatka in na podlagi dobljenih rezultatov ugotovili, da sta metodi zamenljivi. Zaključili smo, da je ${ }^{1} \mathrm{H}$ NMR uporabna metoda za kontrolo kakovosti vhodnih PS in hitra metoda za spremljanje razgradnje PS s hidrolizo in oksidacijo. Tudi novo odkrito nečistoto v vhodnem PS, dolgoverižni keton 12-trikozanon, lahko identificiramo $\mathrm{z}$ uporabo ${ }^{1} \mathrm{H}$ NMR. 